\title{
Test of dissolution and comparison of in vitro dissolution profiles of coated ranitidine tablets marketed in Bahia, Brazil
}

\author{
Aníbal de Freitas Santos Júnior1,"*, Igor Santos Barbosa1, Venyson Lima dos Santos², \\ Rangel Leal Silva², Edimar Caetite Junior ${ }^{2}$
}

\author{
${ }^{1}$ Department of Life Sciences, State University of Bahia, Salvador, Bahia, Brazil, ${ }^{2}$ Department of Health, \\ State University of Feira de Santana, Feira de Santana, Bahia, Brazil
}

\begin{abstract}
Ranitidine is an antisecretory drug with $\mathrm{H}_{2}$ antagonist action useful in treating gastric and duodenal disorders. The dissolution test is used to obtain and compare dissolution profiles and establish similarities of pharmaceutical forms. The aim of this study was to compare the dissolution profiles of 150-mg coated ranitidine tablets of a reference drug (product A) and a generic (product B) and a similar (product C) drug marketed in Bahia, Brazil using a simple, fast and inexpensive ultraviolet method. Dissolution was determined using a USP type 2 apparatus at $50 \mathrm{rpm}$ with $900 \mathrm{~mL}$ of distilled water at $37.0 \pm 0.5^{\circ} \mathrm{C}$ for $1 \mathrm{~h}$. The dissolution test was performed in compliance with the American Pharmacopoeia (USP-32). Dissolution efficiency and difference (f1) and similarity (f2) factors were calculated and evaluated. The proposed quantification methodology for drug dissolution test was validated, presenting accuracy, linearity and precision within the acceptance criteria. Products A, B and C showed dissolution efficiency values of 59.29, 73.59 and $66.67 \%$, respectively. Factors $\mathrm{f} 1$ and $\mathrm{f} 2$ were calculated and showed that the profiles of products A, B and C were dissimilar. However, all the products released ranitidine satisfactorily, with at least $80 \%$ of the drug dissolved within $30 \mathrm{~min}$.
\end{abstract}

Uniterms: Ranitidine/coated tablets/dissolution test. Coated tablets/dissolution test. Spectrophotometry/ drug analysis.

A ranitidina é um fármaco antissecretor, antagonista $\mathrm{H}_{2}$, usado no tratamento de desordens gástricas e duodenais. O teste de dissolução é utilizado para obter e comparar perfis de dissolução, estabelecendo semelhança de formas farmacêuticas. Este estudo tem por objetivo comparar perfis de dissolução de comprimidos revestidos contendo $150 \mathrm{mg}$ de ranitidina, em medicamentos de referência (produto A), genérico (produto B) e similar (produto C) comercializados na Bahia-Brasil, usando um método ultravioleta simples, rápido e de baixo custo. As condições que permitiram a determinação da dissolução foram: aparelho USP tipo 2 a $50 \mathrm{rpm}$, contendo $900 \mathrm{~mL}$ de água destilada mantida a $37,0 \pm 0,5{ }^{\circ} \mathrm{C}$, durante $1 \mathrm{~h}$. O teste de dissolução foi realizado em conformidade com a Farmacopeia Americana (USP32). Cálculo da eficiência de dissolução e fatores de diferença (f1) e semelhança (f2) foram avaliados. A metodologia proposta para a quantificação do fármaco no ensaio de dissolução foi validada apresentando precisão, linearidade e exatidão dentro dos critérios de aceitação. Os produtos A, B e C mostraram eficiência de dissolução de 59,29, 73,59 e 66,67\%, respectivamente. Calcularam-se os fatores f1 e f2 e mostrou-se que os perfis não foram semelhantes para os comprimidos de produtos A, B e C. No entanto, todos os produtos liberaram o fármaco satisfatoriamente, pois, pelo menos, $80 \%$ de ranitidina foram dissolvidos em $30 \mathrm{~min}$.

Unitermos: Ranitidina/comprimidos revestidos/teste de dissolução. Comprimidos revestidos/teste de dissolução. Espectrofotometria/análise de fármacos.

\footnotetext{
*Correspondence: A. F. Santos Júnior. Departamento de Ciências da Vida, Universidade do Estado da Bahia. Rua Silveira Martins, 2555, Cabula, 41150-000 - Salvador - BA, Brasil. E-mail: prof.anibal@ig.com.br
} 


\section{INTRODUCTION}

Ranitidine is an antisecretory drug from the $\mathrm{H}_{2}$-antagonist pharmacological class. It is used in the treatment of gastric and duodenal disorders, such as gastroesophageal reflux disease (GERD), gastritis, peptic ulcer disease, Zollinger-Ellison, among others (Costa, 2004; Mincis, Mincis, 2009; Xue et al., 2001; Grant et al., 1989; Moraes, 1999). It is well tolerated and rarely presents clinically significant drug interactions or serious adverse reactions, such as diarrhea, vertigo, muscle aches, transient cutaneous eruptions, hypergastrinemia, hepatic dysfunctions, reversible blood cell count changes, bradycardia, atrioventricular block and hypersensitivity reactions (urticaria, angioedema, bronchospasm and hypotension) (Holtz et al., 2007).

Ranitidine has a bioavailability of approximately $50 \%$. Seric concentrations between 300 and $500 \mathrm{ng} \mathrm{mL}^{-1}$ are observable 2-3 $\mathrm{h}$ after oral administration of $150 \mathrm{mg}$, with the maintenance of these levels for 6 to $8 \mathrm{~h}$. About $6 \%$ of the dose is excreted in urine as $\mathrm{N}$-oxide, $2 \%$ as $S$-oxide, and $2 \%$ as desmethyl ranitidine, such as furoic acid analogues (Hoogerwerf, Pasricha, 2006). Ranitidine is highly soluble in water and little cell membrane permeable (Coelho, 2007), being classified as a class III drug according to the Biopharmaceutical Classification System (BCS) proposed by the Food and Drug Administration (FDA). Only Class I (high solubility and high permeability) and some Class III (high solubility and low permeability) drugs can be assessed for bioequivalence by dissolution test alone (Bonamici, 2009).

Currently, monitoring the quality of pharmaceutical solid oral dosage forms (capsules and tablets) has gained greater importance to pharmaceutical companies and regulatory authorities. In Brazil, several drugs are commercially available, such as reference, similar and generic drugs. Both similar and generic drugs must have proven pharmaceutical equivalence to their reference drug. Therefore, profiling and comparison of drug dissolution is a requirement (Brasil, 2007a,b).

One of the required pharmaceutical equivalence tests is the comparison of drug dissolution profiles to that of a reference drug. "The dissolution test is currently used as an in vitro bioequivalence (BE) test, generally for dissolution profile and profile comparison, establishing the similarity of pharmaceutical dosage forms" (Menegola, Steppe, Schapoval, 2007). An ideal dissolution test must provide product quality information as well as some preliminary in vivo/in vitro correlation or biorelevance (Emani, 2006). Therefore, the dissolution test can contribute to the continued evaluation and monitoring of products and the development of new formulations (Ferraz et al., 2005).

Mathematical and statistical methods can be used to evaluate the similarity of drug dissolution profiles. Equations $\mathrm{f} 1$ and $\mathrm{f} 2$ and Rescigno index are mathematical models used to compare dissolution profiles and one-way ANOVA, two-way ANOVA and Chow and $\mathrm{Ki}$ are the main statistical methods used. However, the Food and Drug Administration (FDA) recommends only equations f1 and f2 (O'Hara et al., 1998). Drug dissolution profiles may be distinct due to differences in formulations and manufacturing processes, but the differences must not compromise product bioequivalence (Storpirtis et al., 1999).

While a growing number of studies have investigated the dissolution profiles of oral dosage drug solid forms, the dissolution kinetics of coated ranitidine tablets remains unexplored (Ferraz et al., 2005; Brundusino, Pinto Coelho, Oliani, 1999; Shen, Lee, McKeag, 1995; Alkaysi et al., 1989).

This study aims to compare the dissolution profiles of 150-mg ranitidine coated tablets of reference, generic and similar drugs marketed in Bahia, Brazil using a simple, fast and inexpensive ultraviolet method.

\section{MATERIAL AND METHODS}

\section{Material}

All chemicals used were of analytical grade. Double distilled water was used throughout the experiments. Laboratory glassware was kept in a $10 \% \mathrm{v} / \mathrm{v}$ nitric acid solution overnight and rinsed with deionized water and dried in a dust-free environment before use. Reference ranitidine hydrochloride was obtained from Sigma-Aldrich (USA), whereas ranitidine pharmaceutical formulations were purchased from local drugstores. A ranitidine solution with final concentration of $17.00 \mathrm{mg} \mathrm{mL}^{-1}$ was used to obtain the ranitidine standard curve. Ten aqueous solutions of ranitidine standard were prepared with concentrations ranging from 1.0 to $30.0 \mu \mathrm{g} \mathrm{mL}^{-1}$ and analyzed in triplicate by UV spectrophotometry at $314 \mathrm{~nm}$. Water was purified using a Millipore ${ }^{\circledR}$ system.

The ranitidine tablets used in the dissolution test and for profile comparison were:

\section{Product A}

(Reference product) - drug label content of $150 \mathrm{mg}$ and the following excipients: microcrystalline cellulose, magnesium stearate and Opadry OU-S-7322 (hypromellose, titanium dioxide and triacetin). 


\section{Product $B$}

(Generic product) - drug label content of $150 \mathrm{mg}$ and the following excipients: microcrystalline cellulose, magnesium stearate, povidone, colloidal silicon dioxide, croscarmellose sodium, hypromellose, polyethylene glycol, titanium dioxide and ethyl alcohol)

\section{Product $C$}

(Similar product) - drug label content of $150 \mathrm{mg}$ and the following excipients: microcrystalline cellulose, lactose, magnesium stearate, colloidal silicon dioxide, croscarmellose sodium, hypromellose, polyethylene glycol, titanium dioxide and ethylcellulose.

The coated ranitidine tablets were submitted to average weight, friability, disintegration and dissolution tests following the Brazilian Pharmacopoeia general methods applied to drugs.

\section{Instrumentation}

Ranitidine coated tablets were submitted to average weight, disintegration and dissolution tests following the official compendia. An electronic balance (Sartorius), a UV spectrophotometer (Varian model CARY 100 Bio, Australia), a disintegration test apparatus Nova Ética (Model 301/AC 01, Brazil) and a dissolution test apparatus Nova Ética (Model 299, Brazil) multi-bath $(n=6)$ were used in accordance with the United States Pharmacopoeia (USP 32) general methods.

\section{Dissolution test conditions}

Dissolution tests were performed in compliance with USP-32 (USP, 2009) using an apparatus 2 (paddles) at $50 \mathrm{rpm}$ and $900 \mathrm{~mL}$ of dissolution medium (distilled water) at $37.0 \pm 0.5^{\circ} \mathrm{C}$ for $1 \mathrm{~h}$. Manual sampling aliquots of $10.0 \mathrm{~mL}$ were taken at $5,10,15,20,30,40,50$ and $60 \mathrm{~min}$ after dissolution optimization and analyzed. The medium was replaced at $37 \pm 0.5^{\circ} \mathrm{C}$ to a constant volume. The collected aliquots were filtered and transferred to amber vials for subsequent $U V$ spectrophotometry reading (Varian model CARY $100 \mathrm{Bio}$ ) at $314 \mathrm{~nm}$. The standard solution used in all dissolution tests was prepared from an amount of ranitidine transferred to a $50-\mathrm{mL}$ volumetric flask with the dissolution medium $\left(17.0 \mathrm{mg} \mathrm{mL}^{-1}\right)$. The absorbency values were converted to concentrations values with the standard curve equation taking into account the amount of drug removed in each aliquoting; the results were expressed as percentage as a function of time.

In this study, the independent model simple method employing the difference (f1) and similarity (f2) factors was used to compare the dissolution profiles, in accordance with Resolution 31/2010 of the National Sanitary Surveillance Agency (Agência Nacional de Vigilância Sanitária, ANVISA) (Brasil, 2010b). Factor f1 indicates the percentage difference (dissimilarity) between two dissolution profiles; $\mathrm{f} 2$ is the logarithm of the reciprocal square root transformation of the sum squared error. It indicates the average percentage of similarity between two dissolution profiles. Acceptable f1 values are between 0 and 15, while f 2 values are between 50 and 100 . An $\mathrm{f1}$ value over 15 indicates significant dissimilarity and an $\mathrm{f} 2$ value over 50, significant similarity (Gupta, Gaud, Srinivasan, 2010).

\section{Dissolution Efficiency (DE)}

The DE was obtained from the area under the drug dissolution curve (AUC) up to time $t$ in minutes in relation to $100 \%$ of the product label value (Banakar, 1992; Moore, Flanner, 1996; Costa, Sousa Lobo, 2001). The DE was determined as the ratio between the area under the dissolution curve of ranitidine for the time interval from zero to $60 \mathrm{~min}\left(\mathrm{AUC}_{0-60 \mathrm{~min}}\right)$ and the total area of the rectangle $\left(\mathrm{ASC}_{\mathrm{TR}}\right)$ was defined by the ordinate $(100 \%$ dissolution) and the abscissa (time equal to $60 \mathrm{~min}$ ). The efficiency of dissolution is not comparative parameter of dissolution kinetics, but a parameter which characterizes drug release. The $\mathrm{DE} \%$ results of the tested products were submitted to variance analysis (ANOVA).

\section{Validation of the analytical method}

In order to demonstrate whether the dissolution test method was adequate, it was validated following ANVISA Resolution No 899 (Brasil, 2003). Thus, linearity, precision (repeatability and intermediate precision) and accuracy were assessed.

The linearity was obtained through the correlation coefficient of three standard curves with ten different aqueous solutions concentrations from 1.0 to $30.0 \mu \mathrm{g} \mathrm{mL}^{-1}$. Solutions with concentrations of 1.0, 15.0 and $30.0 \mu \mathrm{g} \mathrm{mL}^{-1}$ were prepared for triplicate study of precision and accuracy. Aliquots of a $17.0-\mathrm{mg} \mathrm{mL}^{-1}$ solution of ranitidine reference standard were prepared with distilled water and transferred to volumetric flasks to obtain the final concentrations; absorbance was determined at $314 \mathrm{~nm}$. Linearity was evaluated by linear regression analysis using the least squares regression method.

Repeatability and intermediate precision were used to assess the precision of the method. Relative standard 
deviation (RSD) was used to calculate the precision of quantification of three known concentrations of ranitidine $\left(1.0,15.0\right.$ and $\left.30.0 \mu \mathrm{g} \mathrm{mL}^{-1}\right)$ on the same and on alternate days. Each concentration was prepared in duplicate and analyzed in triplicate in a UV-VIS spectrophotometer on two consecutive days in the same spectrophotometer by the same operator.

Accuracy was expressed as the agreement between the set reference value and the measured value of each concentration. Each concentration (1.0, 15.0 and $30.0 \mu \mathrm{g} \mathrm{mL}^{-1}$ ) was analyzed in triplicate in a UV-VIS spectrophotometer.

\section{RESULTS AND DISCUSSION}

To assess the method linearity, calibration curves of ranitidine concentration $\left(\mu \mathrm{g} \mathrm{mL}^{-1}\right)$ versus absorbance were plotted, giving a correlation coefficient of approximately 0.9997 in the concentration range studied (1.0 to $\left.30.0 \mu \mathrm{g} \mathrm{mL}^{-1}\right)$. The representative linear equation was $y=0.0472 x-0.0293$. The data were validated by analysis of variance (ANOVA) and presented significant linear regression and no significant linearity deviation $(\mathrm{p}<0.05)$ (Brasil, 2010b). Ranitidine concentration measurement Accuracy was determined by same- (intraday) and alternate-day (interday) spectrophotometry in dissolution test standardized conditions. The average recovery was obtained in the range from 96.50 to $102.87 \%$. The relative standard deviation (RSD) values were less than 5\%, considering the dissolution procedure and analysis method precision satisfactory.

Dissolution profile analysis is an important tool to evaluate formulation development and finished products, for batch quality control and establishing the similarity between a generic formulation and its reference product (Marcolongo, 2009). Simultaneous assessment of the chemical and physical characteristics of the excipients present in the analyzed product is critical to justify possible variations in tablet mass as well as in friability, disintegration and dissolution results (Rowe, Sheskey, Quinn, 2009; Gil, Brandão, 2007).

The immediate release tablet coating does not significantly alter the drug release kinetics of its dosage form. The coating components basically confer protection to the coated material, facilitate swallowing or mask unpleasant tastes (Rowe, Sheskey, Quinn, 2009; Gil, Brandão, 2007). The coating compounds of the tested products are a film-forming agent, a plasticizing agent and an opacifier agent. Products A, B and C are coated with the same film-forming agent and opacifier agent, hypromellose and titanium dioxide, respectively. Product
A uses triacetin as a plasticizer and products $\mathrm{B}$ and $\mathrm{C}$ use polyethylene glycol.

Products A and B use only microcrystalline cellulose as a formulation diluent, while Product $\mathrm{C}$ uses lactose, which are water insoluble and soluble, respectively. Lactose gives the tablet a more homogeneous appearance, since microcrystalline cellulose has diluting and disintegrating functions. All the products use magnesium stearate as a lubricant, which can hinder drug interaction with biological fluids and, therefore, interfere with its release. Only product B uses povidone as a binder. Silicon dioxide, a sliding agent, facilitates the flow of powder through machinery. Formulations B and $\mathrm{C}$ use croscarmellose sodium as a disintegrating agent, facilitating the release of the drug for absorption (Rowe, Sheskey, Quinn, 2009; Gil, Brandão, 2007).

The results showed that drugs $\mathrm{A}, \mathrm{B}$ and $\mathrm{C}$ have satisfactory average weight values (Figure 1) according to the American Pharmacopoeia (USP-32). Product B tablets are more uniform and have a lower coefficient of variation than products $\mathrm{A}$ and $\mathrm{C}$.
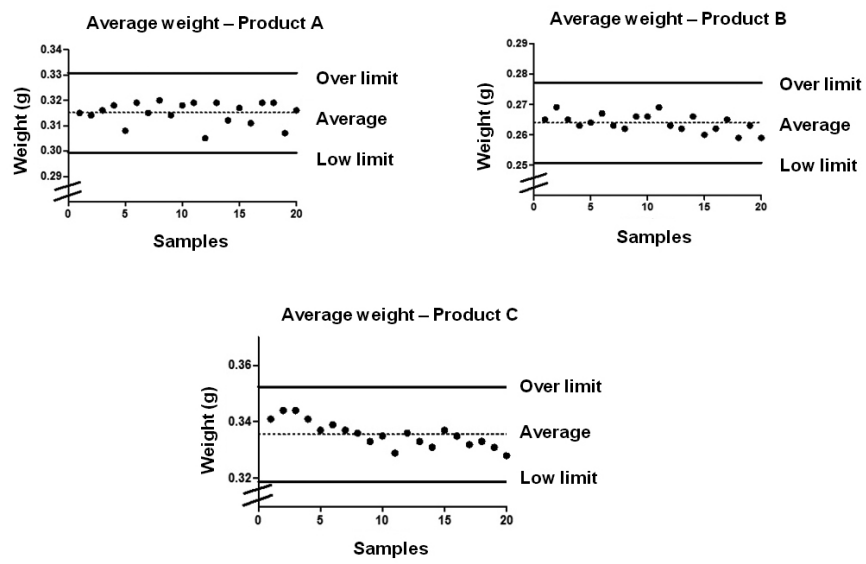

FIGURE 1 - Average weight of coated tablets of products A, B and $\mathrm{C}$.

The tested products had satisfactory disintegration results. All samples disintegrated within 4 to $10 \mathrm{~min}$. Therefore, all samples met the official compendium requirement of 30-min dissolution. Products B and $\mathrm{C}$ disintegrated faster, possibly due to the presence of disintegrating agents croscarmellose sodium and microcrystalline cellulose. Lactose, used in product $\mathrm{C}$, may also have favored disintegration.

The Brazilian Pharmacopoeia (Brasil, 2010a) recommends that not less than $80 \%$ of the ranitidine label amount (150 mg) must dissolve within $45 \mathrm{~min}$. Several factors may influence dissolution results, such as the nature of the excipients and coating used and the rate of 
disintegration. Figure 2 gives the levels of ranitidine in the dissolution media at $45 \mathrm{~min}$.

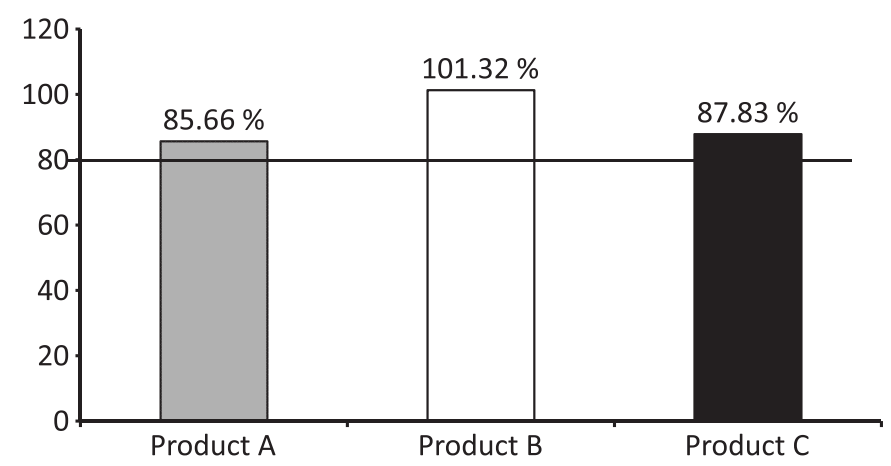

FIGURE 2 - Ranitidine dissolved from coated tablets (150 mg) of products $\mathrm{A}, \mathrm{B}$ and $\mathrm{C}$ within $45 \mathrm{~min}$.

All products were analyzed according to the official compendium recommendations. Products A and C showed comparable levels in the studied time frame. This suggests that the active principle from coated tablets of products $\mathrm{A}$ and $\mathrm{C}$ dissolves proportionally to time in water. However, dissolution kinetics calculations are required to verify which model matches the profiles obtained.

Dissolution time analysis, proposed by the Brazilian Pharmacopoeia (Brasil, 2010a), is punctual and provides few dissolution process data. Therefore, to understand how the pharmaceutical form releases the drug over time, multipoint analysis is essential. Multipoint analysis graphs were plotted to evaluate the amount of the drug dissolved versus time (Figure 3).

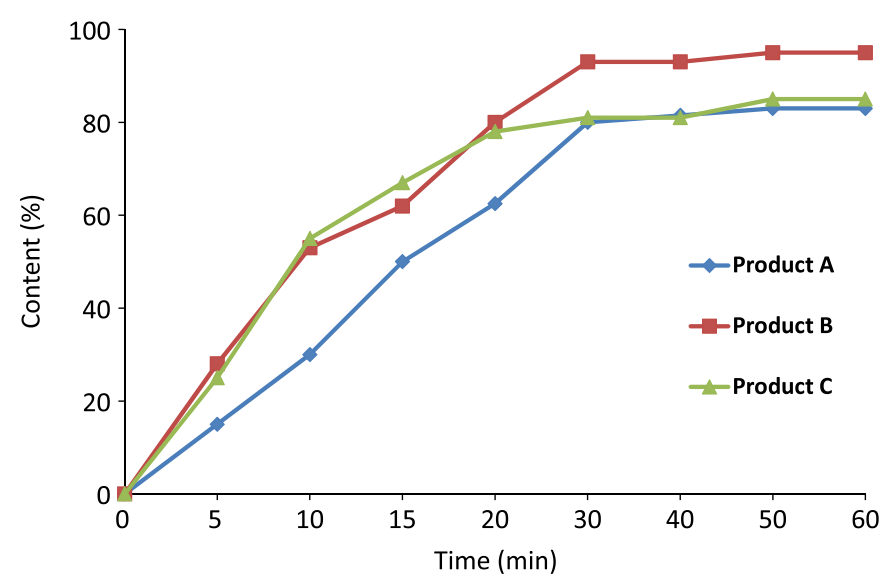

FIGURE 3 - Dissolution profiles of ranitidine coated tablets (150 mg) of products A, B and C. (USP type 2 apparatus at $50 \mathrm{rpm}$ with $900 \mathrm{~mL}$ distilled water at $37.0 \pm 0.5{ }^{\circ} \mathrm{C}$ for 1 ).

Since the dissolution profiles for $20 \mathrm{~min}$ of analysis were similar, visual analysis was performed to determine which product released the active principle the soonest. After $20 \mathrm{~min}$, the release from product $\mathrm{C}$ stabilized, while that of product $\mathrm{B}$ continued with the ensuing increase in the concentration of ranitidine in the medium until it stabilized after $30 \mathrm{~min}$ of test. This concentration was significantly higher than those of the other products. After $30 \mathrm{~min}$, the dissolution profiles of products $\mathrm{A}$ and $\mathrm{C}$ practically superimposed, indicating similar drug dissolution until the end of the test. Product $\mathrm{C}$ had a dissolution profile similar to the other two products, differing only in the dissolution time. It resembled that of the product $B$ from 0 to $20 \mathrm{~min}$ and that of product $A$ from 30 to $60 \mathrm{~min}$.

The analysis of the dissolution profiles of products $\mathrm{A}, \mathrm{B}$ and $\mathrm{C}$ showed a difference in the release of ranitidine in the first 10 min, especially for product A, which may have been related to the product formulation, as it does not use croscarmellose sodium as a disintegrant.

In order to compare the dissolution profiles, mathematical methods, equations f1 (difference factor) and $\mathrm{f} 2$ ( similarity factor), were used. Factors $\mathrm{f} 1$ and $\mathrm{f} 2$ were calculated according to the criteria in the literature (Brasil, 2010b). The results are given in Table I.

TABLE I - Factors $\mathrm{f} 1$ and $\mathrm{f} 2$ of products A, B and C

\begin{tabular}{lcc}
\hline Comparison & $\boldsymbol{f 1}$ & $\boldsymbol{f 2}$ \\
\hline Product A x Product B & 26.52 & 39.00 \\
\hline Product A x Product C & 17.02 & 43.23 \\
\hline Product B x Product C & 8.12 & 49.45 \\
\hline
\end{tabular}

Factors $\mathrm{f} 1$ and $\mathrm{f} 2$ were different and below the requirements for products $\mathrm{B}$ and $\mathrm{C}$ when compared to product $\mathrm{A}$, with better results for product $\mathrm{C}$. The dissolution profiles of products $\mathrm{B}$ and $\mathrm{C}$ were very close to the recommendations. The difference factor (f1) gives the percentage difference between two curves at each reading time and is a measure of the relative error between the two curves. On the other hand, the similarity factor (f2) is the most appropriate method to compare release profiles. The difference factor (f1) gave values within the specified limits and the similarity factor (f2) was very close to the acceptance limit (49.45). The comparison of dissolution profiles using $\mathrm{f} 1$ and $\mathrm{f} 2$ is easy to understand, gives reliable results, also being widespread and the most recommended method by the FDA (FDA, 1997).

Ranitidine release from coated tablets was also assessed through dissolution efficiency (DE). If a drug has high dissolution efficiency, one can infer that the active principle remains in contact with physiologic membranes for a long time and, thus, has a great bioavailability in the 
assessed concentration range. The equations of $\mathrm{fl}$ and f2 were used to compare the formulations under study. Products A, B and C had dissolution efficiency values of $59.29,73.59$ and $66.67 \%$, respectively. The analysis of variance (ANOVA) revealed a statistical difference $(p<0.05)$ between the products. Differences in the DE data may be related to the dissolution profiles of the products, since factors such as tablet coating (film), polymorphism and biopharmaceutical factors may influence the release of the active principle.

This analysis allowed us to evaluate the actual amount of drug dissolved in the medium, which is indicative of a better in vivo test result, considering that drug bioavailability depends exclusively on the amount of drug dissolved in the enteric medium.

\section{CONCLUSIONS}

Ranitidine is classified as a Class III drug (high solubility and low permeability) by the BCS. Dissolution tests are essential for the prognosis of dosage form oral absorption and bioequivalence of drugs. Ranitidine samples were analyzed using a validated UV spectrophotometric method. The method validation showed that the dissolution test is suitable for the quantification of ranitidine in coated tablet pharmaceutical form in in vitro studies with linearity, precision and accuracy.

The tested products (reference, similar and generic drugs) had a satisfactory average weight and disintegration results. The dissolution profiles were compared with the use of dissolution efficiency and factors $\mathrm{f} 1$ and $\mathrm{f} 2$, showing that product A, B and C tablets were dissimilar. Drug release was satisfactory for all products, since at least $80 \%$ of the ranitidine was dissolved in the medium within 30 min of the test.

\section{REFERENCES}

ALKAYSI, H.N.; SALEM, M.A.; GHARAIBEH, A.M.; EL-SAYED, Y.M.; BADWAN, A.A. Bioequivalency of ranitidine tablets. J. Clin. Pharm. Ther., v.14, n.2, p.111$117,1989$.

BANAKAR, U.V. Pharmaceutical dissolution testing. New York: Marcel Dekker, 1992. 437 p.

BONAMICI, D. Sistema de classificação biofarmacêutica e bioisenções. São Paulo, 2009. 159 p. [Dissertation of master degree. Faculty of Pharmaceutical Scieneces, University of São Paulo].
BRASIL. Agência Nacional de Vigilância Sanitária. Resolução n.899, 29 maio 2003. Guia para validação de métodos analíticos e bioanalíticos. Brasília: Diário Oficial da União, 02 jun. $2003.16 \mathrm{p}$.

BRASIL. Agência Nacional de Vigilância Sanitária. Resolução Diretiva Colegiada (RDC) n.16, 02 mar 2007. Aprova o regulamento técnico para medicamentos genéricos. Brasília: Diário Oficial da União, p.2016-2017, 2007a.

BRASIL. Agência Nacional de Vigilância Sanitária. Resolução Diretiva Colegiada (RDC) n.17, 02 mar 2007. Aprova o regulamento técnico para medicamento similar. Brasília: Diário Oficial da União, 2007b.

BRASIL. Agência Nacional de Vigilância Sanitária. Resolução Diretiva Colegiada (RDC) n.31, 11 ago 2010. Dispõe sobre a realização dos estudos de equivalência farmacêutica e de perfil de dissolução comparativo. Brasília: Diário Oficial da União, 2010b.

BRUNDUSINO, A.; PINTO COELHO, D.S.B.; OLIANI C. Bioequivalence study of two ranitidine formulations. Eur. Bull. Drug Res., v.7, n.3, p.11-19, 1999.

COELHO, P.M.B.S. Desenvolvimento de formulações de libertação modificada de Ranitidina. Porto, 2007. 264 p. [Thesis of PhD degree. Faculty of Pharmaceutical Sciences, University of Porto].

COSTA, A.J.F.; SILVA, G.A.P.; GOUVEIA, P.A.C.; PEREIRA FILHO, E.M. Prevalência de refluxo gastroesofágico patológico em lactentes regurgitadores. J. Pediatr., v.80, n.4, p.291-295, 2004.

COSTA, P.; SOUSA LOBO, J.M. Modeling and comparison of dissolution profiles. Eur. J. Pharm. Sci., v.13, n.2, p.123133, 2001.

EMANI, J. In vitro - In vivo correlation: from theory to application. J. Pharm. Pharm. Sci., v.9, n.2, p.169-189, 2006.

FOOD AND DRUG ADMINISTRATION. Guidance for industry: dissolution testing of immediate release solid oral dosage forms. U.S. Department of health and human services, Food and Drug Administration, Center for drug evaluation and research (CDER). Rockville: FDA, 1997. p.1-17. 
FERRAZ, H.G.; OLIVEIRA, G.G.G.; SANTOS, A.L.; BUSCARIOLI, A.C., ROSA, A.B., BARBIERI, F.; FREITAS, J.C.; CANOVA. R. Avaliação do perfil de dissolução dos comprimidos de ranitidina $150 \mathrm{mg}$ disponíveis no mercado Brasileiro. Rev. O.F.I.L., v.15, n.1, p.29-34, 2005.

GIL, E.S.; BRANDÃO, A.L.A. Excipientes: suas aplicações e controle físico-químico. 2.ed. São Paulo: Pharmabooks, 2007. 285 p.

GRANT, S.M.; LANGTRY, H.D.; BROGDEN, R.N. Ranitidine. An updated review of its pharmacodynamic and pharmacokinetic properties and therapeutic use in peptic ulcer disease and other allied diseases. Drugs, v.37, n.6, p.801-870, 1989.

GUPTA, A.; GAUD, R.S.; SRINIVASAN, G. Development of discriminating dissolution method for an insoluble drug: nisoldipine. Int. J. Pharm. Tech. Res., v.2, n.1, p.931-939, 2010 .

HOLTZ, J.V.S.; GRANDI. L.M.; ECCLISSATO, P.R.; BERNARDO, W.M. Há benefício no uso da ranitidina em pacientes hospitalizados, sob menor regime de estresse, na profilaxia da úlcera péptica ou da hemorragia digestiva? Rev. Assoc. Med. Bras., v.53 n.6, p.476-477, 2007.

HOOGERWERF, W.A.; PASRICHA. P.J. Tratamento de úlceras pépticas e da doença do refluxo gastresofágico. In: GOODMAN-GILMAN, A.; BRUNTON, L.L.; LAZO, J.S.; PARKER, K.L. (Eds.). As bases farmacológicas da terapêutica. 11.ed. Rio de Janeiro: McGraw-Hill Interamericana Editora, 2006. cap.37, p.869-881.

MARCOLONGO, R. Dissolução de medicamentos: fundamentos, aplicações, aspectos regulatórios e perspectivas na área farmacêutica. São Paulo, 2002. 117 p. [Thesis of PhD degree. Faculty of Pharmaceutical Sciences, University of São Paulo].

MENEGOLA, J.; STEPPE, M.; SCHAPOVAL, E.E.S. Dissolution test for citalopram in tablets and comparison. Eur. J. Pharm. Biopharm., v.67, n.2, p.524-530, 2007.
MINCIS, M.; MINCIS, R. Helicobacter pylori e câncer gástrico: avanços nos conhecimentos. Einstein: Educ. Contin. Saúde, v.7, n.2, p.66-67, 2009.

MOORE, J.W.; FLANNER, H.H. Mathematical comparison of dissolution profiles. Pharm. Tech., v.20, p.64-74, 1996.

MORAES, S.P.; MELRO, A.P.C.; LONGO, A.; GUN, P.R.; SILVA, M.A.J.; REIS NETO, J.A. Influence of H2 -blockers in the gastric healing process. Rev. Col. Bras. Cir., v.26, n.3, p.153-155, 1999.

O'HARAA, T.; DUNNEA, A.; BUTLERA, J.; DEVANEA, J. A review of methods used to compare dissolution profile data. Pharm. Sci. Technol. Today, v.1, n.5, p.214-223, 1998.

ROWE, R.C.; SHESKEY, P.J.; QUINN, M.E. Handbook of pharmaceutical excipients. 6.ed. London: Farmaceutical Press, 2009. 888 p.

SHEN, J.; LEE, D.; MCKEAG, R.G. Bioequivalency of two forms of ranitidine. New Zealand Pharm., v.15, n.10, p.2435,1995 .

STORPIRTIS, S., OLIVEIRA, P.G., RODRÍGUEZ, D. MARANHO, D. Considerações biofarmacotécnicas relevantes na fabricação de medicamentos genéricos: fatores que afetam a dissolução e a absorção de fármacos. Rev. Bras. Ciênc. Farm., v.35, n.1, p.1-16, 1999.

United States Pharmacopeial Convention (USP). The United States Pharmacopeia. 32.ed. The national formulary. Rockville: United States Pharmacopeial Convention, 2009. 946 p.

XUE, F.B.; XU, Y.Y.; WAN, Y.; PAN, B.R.; REN, J.; FAN, D.M. Association of $\mathrm{H}$. Pylori infection with gastric carcinoma: a meta analysys. World J. Gastroenterol., v.7, n.6, p.801804, 2001.

Received for publication on $06^{\text {th }}$ February 2013 Accepted for publication on $15^{\text {th }}$ August 2013 
